\title{
Sjednocení odloženo. Rozpad levicového volebního kartelu a prezidentské volby ve Francii po otřesech roku 1968
}

\section{Uniting postponed. Dissolution of the Left-wing Electoral Cartel and Presidential Election in France After Disturbance of 1968}

Martin Hromek / martin.hromek@email.cz

Historia Europeana, z. s.

\begin{abstract}
In 1965 the French left-wing parties joined forces and lent support to their common presidential candidate François Mitterrand. However several left-wing candidates ran for President in the following election in 1969. What were the reasons for suspending the unification process? Was it the occupation of the Czechoslovakia or student riots in 1968? Could that be ideological divergences or personal conflicts between French left-wing forces? The article is based on analysis of press releases, political science research made in the 1960s and observations of the Czechoslovak embassy in Paris.
\end{abstract}

\section{Keywords}

left-France; Communist party; presidential election; socialism 
Od roku 1962 Francie volí svého prezidenta v přímé dvoukolové volbě. První volby, které se řídily novými pravidly, se konaly roku 1965. V jejich druhém kole se střetli dosavadní hlava státu Charles de Gaulle a společný kandidát levice François Mitterrand. Pátá francouzská republika a její ústava zakládající většinový volební systém samy o sobě nepřinesly sjednocení roztř̌ištěných levicových sil, ačkoliv by to vycházelo z logiky takového politického uspořádání. Nic na tom nezměnily ani zmíněné prezidentské volby. Levicové strany sice podpořily jednoho jediného politika, který je měl reprezentovat, k úzké spolupráci až slučování jednotlivých levicových stran alespoň prozatím nedošlo. Jistá forma koordinace před jednotlivými volbami různých úrovní však pokračovala i v dalších letech. A přesto se v následujících předčasných prezidentských volbách v roce 1969 proti jednomu představiteli pravice a jednomu reprezentantovi politického středu postavili hned čtyři levicoví kandidáti. Jak k tomu došlo? V čem tkvěly příčiny takto bezprecedentního tř́šš̌ní sil? Následující řádky se pokusí nejen odpovědět na tyto otázky, ale také zhodnotit význam jednoho z mnoha rozkolů zaznamenaných v politickém životě Francie.

Rozpady koalic, hnutí a dalších uskupení neodmyslitelně patří k jakémukoli zřízení postavenému na soupeření politických stran. Zkoumání osudu levicového volebního kartelu v bouřlivém roce 1968 a krátce po něm však mohou být příspěvkem ke studiu dopadů dvou zásadních událostí, tedy vnitřní krize francouzského státu vyvolaná událostmi z května a června 1968 a okupace Československa vojsky Varšavské smlouvy v srpnu téhož roku.

Konec volební spolupráce levicových sil před volbami v červnu roku 1969 je zároveň významným milníkem ve vývoji stranického systému páté francouzské republiky. Jak vyplývá z výše řečeného, strany zastávající levicový program byly takříkajíc odsouzeny ke spolupráci, měly-li aspirovat na volební úspěch. Do čela tzv. volebního kartelu sice postavily poměrně neokoukanou tvář Françoise Mitterranda, žádná z nich se zároveň nedokázala vzdát své tradiční identity. Zatímco na pravici existovalo gaullistické hnutí, které se průběžně transformovalo podle konkrétních potřeb své doby, levice se pokusila o koordinaci na bázi stávajících politických struktur. Právě turbulentní rok 1968 odhalil nedostatky takového postupu. Neexistoval společný program, jednotlivé tradiční strany vycházely ze svých specifických ideologických pozic, levicový tábor reprezentovala celá řada výrazných osobností s více či méně odlišnými názory. Když tedy ve Francii a na mezinárodní scéně nastaly situace, které si žádaly zásadní a rychlá rozhodování, levice jako celek jich nebyla schopná. Studie se pokusí nejen popsat podobu a slabiny zmíněného volebního kartelu a způsob, jak se jeho složky vyrovnávaly se vším, co přinesl rok 1968, ale rovněž naznačit vyústění krize a rozkladu kartelu, jímž byla především hluboká transformace francouzské levice, tedy částečné opuštění tradičních schémat a postupný příklon k systému jedné dominantní levicové strany.

Autorova analýza se bude opírat o zprávy a komentáře dobového francouzského a československého tisku, soudobé politologické studie a pozorování československé diplomatické služby. 


\section{Politická mapa francouzské levice po roce 1965}

Francouzskou levici ve sledovaném období reprezentovalo hned několik politických stran. Existovala zde politická uskupení, jejichž historie sahá až do dob třetí republiky. ${ }^{1}$ Ta disponovala nejpočetnější členskou základnou a největším volebním potenciálem. Především to byla Francouzská komunistická strana (Parti communiste français, dále jen PCF), kterou v tomto období pravidelně volila nejméně pětina voličů. Přes tento fakt se komunisté nemohli stát jádrem sjednocení levicových sil, nebot’ se vyrovnávali s neblahým stalinistickým dědictvím, díky čemuž byli pro většinu Francouzů nepřijatelnou politickou silou. Vytýkána jim byla rovněž příliš úzká navázanost na země sovětského bloku. Nové vedení PCF a zejména její generální tajemník Waldeck Rochet od poloviny 60. let 20. století usilovali o její vyvedení z politického ghetta, kde se ocitla již na konci 40. let 20. století. ${ }^{2}$ Ve straně probíhal proces jisté liberalizace směrem k větší otevřenosti k názorům, které neodpovídaly rigidnímu pojetí marxismu. Její ústřední výbor (dále jen ÚV), který zasedal v Argenteuil v roce 1966, v tomto duchu vyzval intelektuály provázané s PCF k promýšlení podoby kýženého sjednocení levice. ${ }^{3} \mathrm{~V}$ politické rovině se to projevovalo příklonem k součinnosti s dalšími představiteli dělnického hnutí, na čemž se komunisté dohodli na XVII. sjezdu PCF konaném roku $1964 .{ }^{4} \mathrm{~V}$ tom také můžeme spatřovat důvod, proč podporovali Mitterranda v obou kolech výše zmíněné prezidentské volby a proč byli i v dalších letech ochotni vyjednávat o vzájemné podpoře kandidátů stran francouzské levice a dokonce vyzývat k dalšímu kroku na cestě ke sjednocení dělnického hnutí, kterým mělo být vytvoření společného volebního a vládního programu.

Další tradiční levicovou stranou Francie byli socialisté, kteří od roku 1905 vystupovali pod názvem Francouzská sekce Socialistické internacionály (Section française de l’Internationale socialiste, dále SFIO). Přes své postavení druhé nejsilnější strany francouzské levice se v 60. letech 20. století nestali jádrem její integrace. Oslabovala je jistá programová rigidnost lpící na programových východiscích, která se od dob čtvrté republiky takřka nezměnila. Ani její vedení, které z velké části tvořili politici aktivní před rokem 1958, nepřesvědčovalo, že by právě SFIO byla stranou, která by mohla spojovat všechny levicově orientované Francouze v prostředí páté republiky. To byl také důvod, proč

1 Její existenci vymezovaly roky $1875-1940$.

2 PCF měla své ministry v prvních vládách čtvrté republiky (1946-1958). Vládli spolu se socialisty a lidovci (Mouvement républicain populaire), hovoříme o období tzv. tripartismu. Aktivně se však zapojili do stávkového hnutí, které zachvátilo zemi na jaře roku 1947. Komunističtí ministři z toho důvodu byli odvoláni z vlády vedené socialistou Paulem Ramadierem. Období tripartismu skončilo a Francouzská komunistická strana končí v opozici, jak jí to bylo doporučeno na prvním zasedání Kominformy. Navíc se ocitá v izolaci poté, co odmítla Marshallův plán, a naopak přijala stalinskou linii a přímočaře podporovala pozice Sovětského svazu.

3 Dubois, Mathieu: Les années 68 : moment programmatique. Le PCF et la CDU à la recherche de l'avenir. Histoire@Politique, 2015/3, č. 27, s. 117-118, https://www.cairn.info/revue-histoire-politique-2015-3-page-109.htm, citováno 28. 2. 2018.

4 Levicové strany měly podle představ komunistů přikročit k podstatně užší formě spolupráce, než ke které se zavázaly v letech 1934 a 1945. Srov. Duhamel, Alain: Le Parti communiste et l'élection présidentielle. Revue française de science politique 16, 1966, č. 3, s. 539, http://www.persee.fr/doc/rfsp_0035-2950_1966_ num_16_3_392943, citováno 16. 5. 2018. 
i socialisté promýšleli možnost sjednocení levice a proč přistoupili na své členství v uskupení nekomunistických levicových sil, které vzniklo před prezidentskými volbami v září roku 1965 jakožto institucionální zázemí kandidatury Françoise Mitterranda. Tak se zrodila Federace demokratické a socialistické levice (Fédération de la gauche démocratique et socialiste, dále FGDS), která se po Mitterrandově neúspěchu nerozpadla, a naopak nastoupila cestu stále hlubší integrace stran, které ji tvořily.

Vedle SFIO se členem Federace stalo nejstarší tehdy existující francouzské politické uskupení, a to radikální strana, jejíž kořeny můžeme hledat již v době tzv. červencové monarchie a která se zformovala do podoby klasické politické strany v roce 1901. Přestože radikálové bývali klíčovým hráčem na politické šachovnici Francie, ve sledovaném období se jednalo snad o nejslabší článek francouzské levice. Již její název byl ve sledovaném období spíše klamný. Původně krajně levicová strana se postupem času na politické ose posouvala stále více do středu. Čistě středový proud v 60. letech nepřevažoval, ovšem i levicovější většina členstva upřednostňovala umírněnější programová řešení prosazovaná výhradně parlamentní cestou. A společným jmenovatelem všech radikálů byl silný antikomunismus. ${ }^{5}$ Intelektuálně poněkud vyčerpaná radikální strana už navíc ani příliš nelákala voliče a ani její členská základna a vnitřní fungování strany nedosahovaly úrovně konkurenční SFIO ${ }^{6}$ Připojení se k určité podobě volebního kartelu pro ni bylo více než žádoucí, proto přes různé výhrady k socialistům vstoupila do FGDS. Její zdrženlivost ji ovšem přímo předurčovala k tomu, aby zůstala členem Federace poněkud pasivním, rozhodně neaspirovala na pozici vůdčí síly francouzské levice.

Taková charakteristika naopak v žádném př́ípadě nemohla platit pro posledního člena FGDS, jímž byla strana, která již patří mezi formace utvořené až v období páté republiky. Konvent republikánských institucí (Convention des institutions républicaines, dále CIR) založil François Mitterrand až roku $1966,{ }^{7}$ tedy v době těsně po skončení prezidentských voleb, kterých se ne zcela neúspěšně zúčastnil coby společný kandidát levice. Posílen touto zkušeností se rozhodl plně využít nastalé situace a stát se středobodem sjednocovacího procesu stran, které ho ve volbách podpořily. Proto nevstoupil do žádného z již etablovaných politických uskupení, a naopak založil zmíněný CIR, který se měl stát ohniskem promýšlení zmíněné integrace. Již kvưli své krátké existenci tvořil Konvent nejslabší článek Federace co do počtu svých členů a sám o sobě ani nebyl pro voliče zvláště atraktivní. Avšak právě osoba jeho zakladatele Françoise Mitterranda z něj činila velmi vlivnou organizaci.

Stranický systém páté republiky obohatilo ještě další menší uskupení, tedy Sjednocená socialistická strana (Parti socialiste unifié, dále PSU). Jak napovídá její název přijatý

5 Fogacci, Frédéric: «Totalement passifs, totalement négatifs»? Le parti radical, la FGDS et la crise de mai-juin 1968. Parlement[s]. Revue d'histoire politique, 2008/1, č. 9, s. 45, 48, https://www.cairn.info/revue-parlements1-2008-1-page-44.htm, citováno 16. 5. 2018.

6 Fogacci, Frédéric: La mouvance radicale et radicale-socialiste sous la $V^{e}$ République, marge centriste ou centre marginalisé? Histoire@Politique, 2011/3, č. 15, s. 134-144, https://www.cairn.info/revue-parlements1-2008-1-page-44.htm, citováno 16. 5. 2016.

7 Jalabert, Laurent: La Convention des institutions républicaines (1964-1971). Vingtième Siècle. Revue d'histoire, 2009/4, č. 104, s. 125-126, https://www.cairn.info/revue-vingtieme-siecle-revue-d-histoire-2009-4page-123.htm, citováno 16. 5. 2016. 
$\mathrm{v}$ roce 1960 , kdy vznikla, mělo se jednat o uskupení, které se mělo stát spojujícím prvkem levice. Ve skutečnosti PSU k sobě nepřitahovala levici jako takovou, nýbrž jen osobnosti naprosto odmítající politický systém páté republiky. Tento fakt ji předurčoval k čistě opoziční pozici, a to i směrem k př́ípadným politickým partnerům. S Konventem ji spojovalo i poněkud intelektuální zaměření s jistým nádechem exkluzivity. ${ }^{8}$ Nikdy se kolem ní nevytvořilo početné voličské jádro a oslabovalo ji rovněž širší názorové rozkročení od více či méně radikálních levicových intelektuálů až po osobnosti zaměřené modernisticky a reformně, jako byl populární Pierre Mendès-France, bývalý ministerský předseda jedné z vlád čtvrté republiky, tehdy ještě člen radikální strany. PSU ovšem stále výrazněji tendovala ke krajně levicovým pozicím, a především se výrazně vymezovala i vưči dalším stranám v levé části politického spektra. To z ní činilo enfant terrible francouzské politiky stojící mimo hlavní proud jakýchkoli integračních procesů.

\section{Levicový volební kartel v roce 1967}

V polovině prosince 1966 došlo k několika jednáním delegací FGDS a PCF. Jejich výsledkem byla dohoda o společném postupu v nadcházejících volbách. Komunisté jako již tradičně požadovali vypracování společného vládního programu obou formací, což bylo jako obvykle odmítnuto. Rozdílné názory panovaly i na strategii vzájemné podpory kandidátů. Zatímco komunisté vylučovali dávat doporučení svým voličům k hlasování za jakéhokoli nelevicového kandidáta, Federaci za přijatelného považovala každého ze zúčastněných zástupců demokratických stran, jenž bude zastávat protigaullistické postoje. ${ }^{9}$ Mezi důvody takové pozice se řadila zejména zahraniční politika, tedy oblast, v níž existovaly nejzásadnější názorové rozpory mezi PCF a Federací. Proevropská a proatlantická orientace stran tvořících FGDS mohl z pohledu komunistů kompenzovat jejich levicový program, ovšem zcela nepřijatelný byl např. Demokratický střed (Centre démocratique) dalšího z prezidentských kandidátů z roku 1965 Lecanueta. ${ }^{10}$ Dohoda se tedy soustředila pouze na témata, na nichž panovala shoda, a to i v mezinárodněpolitických otázkách, které výslovně vyjmenovávala snad proto, aby se tak alespoň částečně vyvážila absence společného programu.

Na vzájemné podpoře svých kandidátů v prvním kole parlamentních voleb se s Federací posléze dohodla i PSU. Stalo se tak dne 20. ledna 1967. Předmětem této dohody již

8 Cayrol, Roland: Le choix du P.S.U. Revue française de science politique 17, 1967, č. 5, s. 933, 937, http:// www.persee.fr/doc/rfsp_0035-2950_1967_num_17_5_393049, citováno 16. 3. 2018.

9 Kupříkladu československé velvyslanectví v Paříži ji mělo za zcela přelomovou, de facto rušící politickou izolaci Francouzské komunistické strany. Srov. Archiv Ministerstva zahraničních věcí České republiky (AMZV), Teritoriální odbory-tajné (TO-T) Francie 1965-1969, kart. 3, sign. 052/311, č. j. 0320/66-SK/ MK, 26. 12. 1966.

10 Zmíněná zpráva to definovala zcela pregnantně. Československý zastupitelský úřad (dále ZÚ) totiž vyslovil naději, že francouzští komunisté raději akceptují gaullistickou většinu, než aby se přiklonili k silám, které údajně plnily zahraničněpolitické cíle Spolkové republiky Německo a Spojených států amerických. Tamtéž. 
nebyly programové otázky, nýbrž výhradně souhlas s vyzváním k hlasování pro nominanta druhé strany v následujícím kole voleb. ${ }^{11}$

Obě předvolební dohody spočívající na obecné shodě a ponechávající velký prostor místním organizacím jednotlivých uskupení ukázaly nemožnost vytvoření plnohodnotné volební koalice levicových stran. Ty rozdělovaly některé programové otázky, a to zejména v oblasti zahraničněpolitické orientace Francie, ale také rozpory v náhledu na výslednou podobu Národního shromáždění. Komunisté si přáli výhradně levicovou většinu. Kdyby jí nebylo dosaženo, preferovali raději pokračování gaullistické vlády, s níž sdíleli pohled na zakotvení Francouzské republiky ve světě. Federace se sice pod vlivem předsedů SFIO a CIR Molleta a Mitterranda rozhodla pro omezenou spolupráci s PCF, primárním cílem FGDS však bylo odstavení de Gaulla a jeho strany od moci. Proto nezavrhla ani vyjádření své podpory nelevicovým kandidátům, zejména představitelům Demokratického středu. Podobná levostředová předvolební dohoda byla ostatně původním cílem radikálư ${ }^{12}$ a části SFIO v čele s Gastonem Defferrem, jenž před rokem 1965 usiloval o svou nominaci pro prezidentské volby právě na základě koordinovaného postupu části levice a středových politických subjektů.

Březnové volby do Národního shromáždění, které byly předmětem zmíněných ujednání, ukázaly, že levice jako celek posílila. A zatímco vítězem se stali pravicoví gaullisté, Demokratický střed utrpěl hořkou porážku. ${ }^{13}$ Francie tak měla směřovat $\mathrm{k}$ bipolarizaci na ose pravice-levice, jak vyplývalo ze samotného principu většinového volebního systému, který přinesla pátá republika. Otevírala se tak cesta k dalšímu prohlubování integrace levé části politického spektra země. Mohlo se tak stát ještě do konání dalších prezidentských voleb, jejichž výsledkem by byla porážka Charlese de Gaulla společným kandidátem levicových uskupení? Již název této stati napovídá, že se tak nestalo.

Již brzy po březnu 1967 se mělo ukázat, že součástí sjednocené levice se zcela jistě nestane PSU. Její spojenectví s FGDS jí přineslo zisk čtyř poslaneckých mandátů, což mělo být pro stranu, která se považovala z avantgardu dělnického hnutí, významným varováním. PSU se přesto pod vlivem svého nového generálního tajemníka Michela Rocarda rozhodla nevstupovat do organizace, kterou nepovažovala za programově kompatibilní se svými představami o ideálním uspořádání státu. ${ }^{14} \mathrm{Na}$ svém V. sjezdu, který se konal ve dnech 23. až 25. června 1967 v Paříži, proto odmítla další případné sbližování

11 Pro první kolo se s generální dohodou nepočítalo, vedením PSU a FGDS byl pouze vymezen prostor pro ad hoc dohody na místní úrovni. AMZV, TO-T Francie 1965-1969, kart. 3, sign. 052/311, č. j. 035/67-Sl/ PJ, 26. 1. 1967.

12 Někteří zástupci radikální strany se odmítli výsledky jednání své strany vázat a dokonce se nepovažovali za reprezentanty FGDS. Jedním z nich byl kupř́ikladu známý představitel radikálů Maurice Faure, který se k Federaci připojil až před druhým kolem voleb. Srov. AMZV, TO-T Francie 1965-1969, kart. 3, sign. 052/311, č. j. 0115/67-Kř Ls, 20. 3. 1967.

13 To s povděkem kvitovalo československé velvyslanectví v Paříži. Lecanuetova strana jím totiž byla označována za proamerickou, tudíž zcela nepřijatelnou pro zájmy komunisty ovládaného Československa. Tamtéž.

14 Federaci byl kupříkladu vytýkán její přríklon k existenci atlantických struktur, zatímco PSU si představovala Evropu zcela nezávislou na Spojených státech amerických. Srov. Cayrol, R.: Le choix du P.S.U., s. 935. 
s FGDS. ${ }^{15}$ A po celé další námi sledované období vstupovala do volebního klání vždy nezávisle a žádných integračních snah se již nezúčastnila.

Její vliv byl ovšem velmi omezený. Daleko zásadnějším pro budoucnost francouzské levice se ukázal další vývoj vztahů mezi PCF a stranami, které tvořily Federaci. Volební výsledky dokazovaly, že se jim vyplácí postupovat koordinovaně. Ve skutečnosti se však programově ani v nejmenším nepřibližovaly a rozdílné názory mezi komunisty na jedné straně a FGDS na straně druhé komplikovaly i hlubší propojování členů Federace. Jistý antikomunismus byl př́tomen u všech. Pro některé ovšem byla PCF tak nepřijatelná, že se bránili směřování FGDS směrem k pokračování spolupráce s komunistickou stranou, kterou i nadále prosazovali zejména Mollet a Mitterrand. ${ }^{16}$

Do situace ve francouzské levici v průběhu roku 1967 výrazně promluvila zahraniční politika, respektive situace na Blízkém východě. Během krize, která vypukla po šestidenní válce, se i mezi francouzskými politickými stranami objevilo ostré dělítko. Zatímco komunisté izraelskou akci ostře kritizovali, socialisté a další členové FGDS Izraeli vyjadřovali podporu. A došlo i na vzájemné obviňování z podléhání vlivu velmocí. Proizraelský postoj byl směšován s proamerickou politikou, naopak napadání židovského státu francouzskými komunisty se považovalo za důkaz jejich fatální provázanosti se stanovisky Komunistické strany Sovětského svazu (dále KSSS). ${ }^{17}$ Přes tyto rozepře se dne 15. června FGDS a PCF ustavily pracovní skupinu sestávající ze tří komisí diskutujících o programových otázkách, ${ }^{18}$ ač jejich činnost až do podzimu 1967 negativně ovlivňovaly rozpory v oblasti zahraniční politiky. Ty byly vysledovatelné i při sestavování kandidátek do kantonálních voleb, které se konaly 24. září a 1. ř́ijna 1967. Případný společný postup levicových stran komplikovaly zejména vztahy mezi jejich místními organizacemi, ovšem opomíjela se ani tzv. velká politika, tedy zásadní názorové rozepře v pohledu na mezinárodní politiku..$^{19}$ Nepomohla tedy ani vyjádření předsedy FGDS Françoise Mitterranda, jenž se pokusil zmírnit jednoznačnost vyjádření členů jeho Federace důrazem na nutnost řešení otázky palestinských uprchlíků a smíření Izraele a arabských zemí. ${ }^{20}$

Poté, co se PSU vzdala dalších snah o sbližování na levici, můžeme od druhé poloviny roku 1967 sledovat dva paralelní procesy. Jedním z nich byla vnitřní integrace nekomunistické levice s výjimkou PSU. Strany tvořící FGDS se soustředily na jednání o budoucnosti tohoto uskupení. Primárním cílem bylo přikročení ke skutečné federalizaci organizace,

15 Tamtéž, s. 932.

16 Vztah většiny socialistů k francouzským komunistům shrnul např. bývalý ministr za SFIO Robert Boulloche, který PCF hodnotil jako stranu „velice zkostnatělou, málo demokratickou“, až př́iliš svázanou se SSSR. Nicméně pro své socialisty neviděl jinou možnost než s ní spolupracovat. Nejlépe ovšem ve svazku $\mathrm{s}$ dalšími stranami sdruženými ve FGDS. Srov. Le congrès de la S.F.I.O. a poursuivi l'examen des problèmes de la Fédération et de ses rapports avec le P.F. Le Monde, 2./3. červenec 1967, s. 7.

17 Československý ZÚ výtky adresované Francouzské komunistické straně socialistickými listy spojoval se zápasem o vedoucí postavení na francouzské levici. Srov. AMZV, TO-T Francie 1965-1969, kart. 3, sign. 052/311, č. j. 0118/67-Kř/Ls, 7. 6. 1967.

18 První komise se zabývala institucemi republiky, druhá hospodářsko-sociálními otázkami a třetí zahraniční politikou. Tamtéz, č. j. 0349/67 Kř /Kž, 13. 12. 1967.

19 AMZV, TO-T Francie 1965-1969, kart. 3, sign. 052/311, č. j. 0270/67-Kř/MK, 12. 9. 1967.

20 Tamtéz̆, č. j. 0723/67-Sl/Ls, 15. 9. 1967. 
tedy k podstatnějšímu programovému průniku, který měla připravovat komise speciálně vytvořená pro tyto účely, a jejího posílení strukturálního propojení na celostátní a departementální úrovni. ${ }^{21}$ Výsledkem debat o ideových cílech FGDS se stala tzv. Deklarace principů, která měla vstoupit v platnost v okamžik sloučení stran tvořících Federaci. Její text zdůrazňuje nutnost prosazení socialistické demokracie postavené na rovnosti a osobní svobodě jednotlivce, které stávající podoba kapitalistické společnosti nemůže zaručit. ${ }^{22}$

Socialisté Deklaraci schválili na svém sjezdu v Suresnes, jenž se konal ve dnech 27. a 28. ledna 1968. Kromě posouzení tohoto textu se sjezd zabýval i návrhem vlivného člena strany Gastona Defferra, který navrhoval dílčí sloučení socialistické strany s Konventem republikánských institucí. Defferre již před rokem 1965, tedy v době, kdy usiloval o svou nominaci na prezidentského kandidáta, uvažoval o širší koalici levicových sil. Nechtěl reprezentovat jen svoji SFIO, v níž převažoval konzervativní duch reprezentovaný Guy Molletem. Většina členů strany trvala na zachování svébytné identity SFIO. ${ }^{23}$ A to se později projevilo i v roce 1968. Defferre zůstal se svým projektem v menšině. Socialisté měli i nadále působit jako samostatná organizace, dokud nedojde ke shodě na sloučení všech součástí FGDS. ${ }^{24}$ Projevila se tak síla vlivu jejich generálního tajemníka Molleta, který byl sice na rozdíl od reprezentantů modernějšího pojetí levicové politiky, jako byli Defferre, Mitterrand nebo Mendès-France, vnímán jako poněkud názorově strnulý matador politiky, pro většinu delegátů sjezdu představoval jistotu programové kontinuity jejich strany.

Druhým procesem byla snaha o koordinaci postupu Federace s Francouzskou komunistickou stranou. Když poněkud utichly vzájemné invektivy vyvolané odlišným názorem na blízkovýchodní otázku, otevřela se cesta k intenzivnějšímu jednání FGDS s PCF, což byl cíl, který sledovali především předseda Federace Mitterrand a generální tajemník SFIO Mollet. Na negociace ovšem došlo až v prosinci 1967, přitom práce zmíněných smíšených komisí byla skončena již 12. ř́ijna. Výsledný text popisoval programové průniky a odlišnosti mezi oběma formacemi. Ty navzájem dělily zejména zahraničněpolitické problémy, jako byla podpora nadnárodního charakteru probíhající evropské integrace ${ }^{25}$ a její rozšíření o Velkou Británii a další země či trvání na zachování atlantických vazeb ne-

21 Tamtéž, č. j. 0342/67-Kř/Ls, 3. 12. 1967.

22 V tomto bodě se dle mínění československého ZÚ Paříž Deklarace plně shoduje s programem SFIO. Srov. AMZV, TO-T Francie 1965-1969, kart. 3, sign. 052/311, č. j. 036/68-Slan/MK, 5. 2. 1968.

23 Sjezd zdůraznil, že fúze stran tvořících FGDS se uskuteční možná jen, pokud bude zaručeno, že se stane socialistickou organizací respektující zásady tvořící ideový základ SFIO. Mnozí delegáti přitom vyjadřovali své pochyby o socialistickém zaměření radikálů a CIR. Srov. Le congrès de la S.F.I.O. a poursuivi l'examen des problèmes de la Fédération et de ses rapports avec le P.F. Le Monde, 2./3. červenec 1967, s. 7.

24 AMZV, TO-T Francie 1965-1969, kart. 3, sign. 052/311, č. j. 09/68-Kř/MK, 11. 1. 1968.

25 Např. lídr Federace Mitterrand explicitně zdůrazňoval, že jedinou možnou perspektivou pro Francii je její účast na budování Společného trhu. Srov. M. François Mitterrand juge et critique. Le Monde, 18. 8. 1967, s. 4. Komunisté naopak tvrdili, že v nadnárodně koncipované Evropě Francii hrozilo nebezpečí neblahého vlivu německého kapitálu. Např. člen PCF a odborový předák Pierre Juquin připouštěl, že ve Francii, svázané s okolními zeměmi západní Evropy, nelze radikálně přebudovávat její hospodářské struktury, evropskou integraci ve stávající podobě však měl za jistý způsob kolaborace s monopolním kapitalismem. Srov. jeho text Pour que la gauche gouverne. La Nouvelle Critique, č. 5 (186), červen 1967, s. 162. 
komunistickými stranami. Těžko překonatelné byly i odlišné pohledy na hospodářskou a sociální politiku země. ${ }^{26}$

Vyvrcholením několikaměsíčních rozhovorů mezi FGDS a PCF měla být jejich společná deklarace ze dne 23. února 1968. Ani ona ovšem nezměnila podstatu vzájemných vazeb na levici. Nemožnost představit veřejnosti společný vládní program Federace a komunistů $^{27}$ a přetransformovat FGDS ve skutečnou federaci, natož jednolitou stranu, mohla vytvářet dojem slepé uličky. Vrcholní představitelé jednotlivých stran nešetřili optimismem, ve skutečnosti se oproti předešlému jaru 1967 téměř nic nezměnilo.

\section{Dvojí krize roku 1968}

Jelikož historie nezná žádné kdyby, nemusíme ani spekulovat, zda mohl výše nastíněný postup sjednocování levice vést $\mathrm{k}$ nějakému přelomovému výsledku. Rok 1968 totiž dosavadní procesy zcela rozvrátil. Do vývoje věcí promluvily dvě zásadní krize, které téměř paralelně hluboce poznamenaly poměry na francouzské politické scéně. Prvotním, zcela kardinálním a také nečekaným problémem byl výbuch nespokojenosti na francouzských vysokých školách v květnu 1968, který se postupně rozrostl v mohutné celospolečenské hnutí a uvrhl zemi do hluboké politické krize. Druhá krize oproti tomu z pohledu vnitropolitické situace Francie působí spíše jako doprovodná mezinárodní komplikace, která podtrhla to, co bylo rozhodnuto na domácí scéně. Byla jí vojenská intervence pěti členských zemí organizace Varšavské smlouvy v Československé socialistické republice (dále ČSSR) z noci na 21. srpna 1968..$^{28}$

Květen 1968 se hluboce zapsal do dějin Francie a je sám o sobě úžasným tématem pro historiky, filozofy, politology, sociology i kulturology. Zásadně ovlivnil i několikaletý proces sjednocování francouzské levice. Každá ze stran události na jaře tohoto roku prožívala poněkud odlišným způsobem. $\mathrm{O}$ tom již bylo napsáno mnoho tisíc stránek odborných studií. Co však udělala s jejich vzájemnými vztahy? V prvé řadě je třeba konstatovat, že zcela definitivně vzdálila PSU od ostatních levicových formací. Sjednocená socialistická strana sice byla názorově dosti heterogenní, jako celek přece jen tendovala $\mathrm{k}$ radikálně levicovým řešením, a měla tak poměrně blízko $\mathrm{k}$ vůdcům studentského hnutí z května

26 AMZV, TO-T Francie 1965-1969, kart. 3, sign. 052/311, č. j. 0342/67-Kř/Ls, 3. 12.1967 a č. j. 0349/67 Kř/Kž, 13. 12. 1967. Rozdíly např. panovaly v názorech na znárodňování. Komunisté ho považovali za zcela zásadní požadavek, zatímco nap̌r. socialisté se obávali, že by díky tomu přspř̌́liš vzrostla moc státu na úkor svobody jedince, která měla být základem nového demokratického socialistického uspořádání země. Nechtěli napodobit vývoj v sovětského bloku, kde dle jejich názoru vládl všemocný stát ve formě byrokraticko-autoritářského režimu. Srov. La recherche théorique dans la SFIO. La Nouvelle Critique, č. 6 (187), zář́ 1967, s. 5-6.

27 Deklarace na jednu stranu vyjmenovává společné cíle všech zúčastněných, jako bylo omezení moci kartelů v rámci Společného trhu, uznání Německé demokratické republiky a definitivnosti německé hranice na Odře a Nise. Na druhou stranu zmiňuje i otázky, na nichž ke shodě nedošlo, aby byla veřejnost přesně obeznámena s odlišnými názory jednotlivých stran nap̌r. na zahraniční politiku nebo na znárodňování klíčových odvětví francouzského hospodářství. Srov. Krok za krokem. Kulturní tvorba VI, 14. 3. 1968, s. 14-15.

28 Obě tyto krize měly leccos společného, mnohé je rozdělovalo. Podrobná analýza ovšem není cílem této stati, která se omezuje na analýzu jejich důsledků na dění na francouzské levici. 
1968. S řadou z nich úzce spolupracovala a sdílela jejich hodnocení soudobé politické situace. Zvolila tedy poněkud odlišný přístup v porovnání se členy FGDS, která zaujímala umírněnější politická stanoviska. Do zcela zásadního rozporu se tím dostala zejména s Francouzkou komunistickou stranou.

PCF v počáteční fázi květnového hnutí spíše rozvažovala, jak zareaguje. Masy nespokojených v ulicích měly být pro komunisty zaštitující se revoluční ideologií teoretickou příležitostí, jak vyvinout tlak na vládní většinu s cílem nastolit pořádky ve shodě se svým programem. V řadě ohledů jim však gaullistická vládní politika konvenovala a vzhledem k ambicím stát se klíčovým aktérem sjednocení levice PCF programově odkládala jakékoli revoluční prvky a opakovala, že jejím cílem je mírová, nerevoluční a specificky francouzská cesta k socialismu. Nyní se tedy bránila vyzývat své příznivce, aby vyšli do ulic a přidali se k protestům. Největší komplikací však představovalo ideové zaměření většiny vůdců studentského hnutí. Ti v PCF spatřovali stranu patřící k establishmentu, nerevoluční, nedůvěryhodnou. Hlásili se k proudům, které byly, ve francouzštině ovšem bez primárně negativního nádechu, označovány coby levičácké (gauchistes): trockisté, maoisté, anarchisté apod. ${ }^{29} \mathrm{Z}$ pohledu komunistů sovětského střihu se jednalo o nositele ideologických úchylek, které byly snad to úplně nejnebezpečnější. Vždyt proti nim celá léta intenzivně bojovali. ${ }^{30}$ PCF se rozhodla do protestního hnutí zapojit, nikoli spolu se studenty, ale vedle nich. Podporovala mohutné stávky, které se šírily po celé zemi, ovšem s důrazem na sociální otázky. Zejména spokojenost komunistů po jednání s vládou o opatřeních, která měla vyjít vstříc požadavkům odborů, ukázala, že PCF ke krizi přistupovala zcela pragmaticky, v žádném př́ípadě s cílem ji využít k převzetí moci. I nadále doufala, že nejlepší cestou k podílu na vládnutí je spolupráce s dalšími levicovými stranami, samožrejmě vyjma PSU.

Jednalo se zejména o FGDS, která však z nastalého vývoje situace vyšla naprosto oslabená. Velmi často se skloňuje zejména fakt, že radikálové a SFIO, ale i Mitterrand z CIR se zaměřovali výhradně na politiku vedenou na parlamentní půdě. K mobilizaci v ulicích neměli ani dostatek prostředků, ani vůle. Tak se protestujícím zcela odcizili. Ztratili tím možnost získat v části z nich voličskou podporu pro předčasné parlamentní volby, které

29 Člen ÚV Francouzské komunistické strany Roland Leroy prohlašoval, že studenti se opravdu k těmto ideologiím hlásili. To bylo nicméně způsobeno jednak podporou údajných nepřátel komunismu, jako byla Čína, ale také jejich původem. Leroy v nich viděl dcery a syny buržoazie, což je dle něj vedlo k přesvědčení, že v čele revolučního hnutí mají být intelektuálové. Zaujal k nim však smířlivý postoj, blahosklonně vyjádřil svou solidaritu s jejich požadavky a nabídl jim program své strany, který by jim měl být blízký. Srov. La politique des communistes. La Nouvelle Critique, č. 15 (196), červen 1968, s. 4-6.

30 V podobném duchu o pařížských událostech referovali i konzervativní přispěvovatelé československých periodik. Obviňovali studentské vůdce hlásící se k trockismu, že hlásali jednotu dělnického hnutí, přitom ji sami rozbíjeli svou kritikou PCF, které vyčítali př́́klon k zahraniční politice gaullistů a závislost na postojích Sovětů. Srov. např. Volf, Rostislav: Setkáni s trockismem. Kulturní tvorba, roč. VI, 13. 6. 1968 , s. 16. Nesmíme ovšem opomenout hlasy vyjadřující jisté sympatie k radikálně levicovým hnutím, která bojují proti „změštáčtění“ a byrokratizaci komunistické strany. Kupříkladu Milan Petr doplnil, že „přece i my prožíváme československou revoluci“. Vyzýval tedy k přemýšlení o vývoji ve Francii oproštěném od případných deformací způsobených neobjektivním zpravodajstvím. Srov. Petr, Milan: A zas rudé vlajky. Kulturní tvorba, roč. VI, 20. 6. 1968, s. 6-7 a týž: Francie nás pořád trápí. Kulturní tvorba, roč. VI, 11. 7. 1968, s. 15. 
byly nutností. ${ }^{31}$ Věnovali se spíše snaze svrhnout vládu hlasováním v Národním shromážděním, která byla předem odsouzena $\mathrm{k}$ nezdaru, protože vládní většina stále existovala. Nepomohlo ani Mitterrandovo vyhlášení ochoty převzít zodpovědnost za zemi v případě odstoupení prezidenta republiky. To totiž přišlo v době, kdy již byla Francie z protestů a stávek unavena. Umírnění voliči, o něž mělo jít Federaci především, si přáli uklidnění situace, nikoli složité hledání jiné vládní většiny a s tím spojenou politickou nestabilitu.

Červencové předčasné volby do Národního shromáždění pro levici skončily naprostou katastrofou. Za strategické chyby, kterých se v průběhu května a června dopustila FGDS, voliči potrestali všechny strany tvořící Federaci. Francie sice zažívala velké protigaullistické vzepětí, nakonec u jejích občanů zvítězila touha po uklidnění situace. Odmítli vládu levice a umožnili gaullistům získat absolutní většinu v dolní komoře, a to poprvé od vzniku páté republiky. Stalo se tak pouze pod dojmem dramatických událostí posledních týdnů, nebo tím vyjádřili nedůvěru k projektu Federace spolupracující s PCF, který se rodil od roku 1965? Tato otázka měla zaměstnat vrcholné představitele levice na několik následujících měsíců.

Mezi poražené ovšem patřila i komunistická strana. Její zapojení do stávkového hnutí využili prezident republiky Charles de Gaulle a jeho strana k vyvolání vlny antikomunismu. Až revoluční nádech událostí na jaře 1968 v mnoha Francouzích vzbudil strach z převratu vedeného právě komunisty, ačkoliv tito byli ze strany studentských vůdců a jejich podporovatelů naopak obviňováni z nedostatku revolučního zápalu. Stejně jako v prezidentských volbách v roce 1965 se dokonce část voličů komunistické strany přiklonila $\mathrm{k}$ podpoře kandidátů gaullistů. Ačkoli PCF nezaznamenala př́mo drtivý propad, i ona musela čelit otázce, jakou další strategii zvolit, aby se vrátila k volebním úspěchům z předcházejícího roku 1967.

Komunisty oslabila i další zmíněná krize roku 1968, a to narůstající konflikt mezi ČSSR a Sovětským svazem, který vyvrcholil okupací Československa v srpnu 1968. Francouzská komunistická strana samozřejmě proces nazývaný Pražské jaro pozorně sledovala. Jako celek byla při jeho hodnocení nejvýše opatrná. Pod vlivem svého generálního tajemníka Waldeck-Rocheta se prezentovala jako strana, která se zbavila stalinistických deformací. Z toho důvodu liberalizační snahy československého vedení neodsuzovala. ${ }^{32}$ Zároveň je ani nepřijala jako celek. V PCF totiž bylo stále velmi vlivné konzervativní křídlo, To sice kurz prosazovaný Waldeck-Rochetem veřejně nezpochybňovalo, myšlenky Pražského jara mu ovšem byly zcela cizí. Hlasy plně podporující československé reformnî hnutí tedy v rámci PCF nebyly rozhodně většinové. ${ }^{33}$

31 Což byla možnost přece jen málo pravděpodobná, protože pro radikálně založené květnové hnutí byly tradiční strany a př́lišs uhlazený CIR jen málo atraktivní.

32 Sympatie Československu vyjadřovala zejména komunistická periodika. Např. La Nouvelle Critique politiku Komunistické strany Československa (KSČ) prosazovanou od přelomu let 1967 a 1968 vítala jako vhodnou odpověd' na dosavadní byrokratický způsob řízení státu, který brzdil rozvoj hospodářství s odkazem na závěry XX. sjezdu KSSS, který měl naznačit, že možných cest k nastolení socialismu je více. Tímto se řídila i PCF, když odmítla revoluční změny poměrů v zemi. Srov. Tchécoslovaquie. Éléments pour un dossier Pourquoi ? La Nouvelle Critique, č. 17 (198), ř́ijen 1968, s. 24-26.

33 Jistou uzavřenost PCF bylo možno klást do protikladu k Italské komunistické straně, jejíž představitelé 
Kompromisem mezi oběma křídly bylo i vyjádření ústředního výboru PCF k invazi vojsk pěti zemí Varšavské smlouvy do ČSSR ze dne 22. srpna 1968. Zatímco politbyro strany předešlého dne tento akt odsoudilo (použilo výraz réprobation), ÚV jako celek vyslovil pouze svůj nesouhlas (v textu se objevilo významově jemnější désapprobation). Postupem času se jednotlivá usnesení strany k československé otázce stále více blížila sovětským postojům. ${ }^{34}$ A to byla voda na mlýn všem kritikům komunistické strany a její politiky. K nim se řadila i valná členstva dalších levicových uskupení. Architekti projektu sbližování FGDS s PCF Mitterrand a Mollet zaujali poměrně umírněné stanovisko, které se spokojilo s odmítnutím okupace Československa, aniž by jím chtěli ohrozit své plány. ${ }^{35}$ Šlo jim samozřejmě zejména o pokračování sbližování celé francouzské levice, o něž dlouhodobě usilovali. Opominout by se neměla ani jejich obava z narušení stability na evropském kontinentu, jejíž součástí byla v této době i existence dvou mocenských bloků. ${ }^{36}$ Zesílil i výše zmíněný antikomunismus v rámci SFIO a zejména mezi členy radikální strany, takže perspektiva jednoty postupu celé francouzské levice se značně zkomplikovala. Léto roku 1968 tedy levicovým uskupením příliš nepřálo. Volební porážka a vlna antisovětských nálad po vpádu do ČSSR je dostaly do pozice, kdy každé z nich muselo řešit svou vlastní budoucnost i výhledy na jejich př́ípadnou další kooperaci. Bylo možné pokračovat v projektu federace nekomunistické levice? Mělo se navázat na vyjednávání o jejím společném programu s komunistickou stranou?

Asi nejméně dramatické bylo dění uvnitř PCF. Průběh roku 1968 stranu nepřiměl ke změně ve svém vedení. V jeho čele zůstal generální tajemník Waldeck-Rochet, ačkoli

myšlenky Pražského jara studovali a snažili se jim porozumět. Srov. Roger Garaudy o tř́dních vztazích a socialismu. Listy, roč. 2, č. 9, 6. 3. 1969, s. 9.

34 PCF upozorňovala, že se vedení KSČ nedostatečně vymezilo vưči údajně nepřátelským silám a nebezpečí německého revanšismu. Srov. Grémion, Pierre: Paris-Prague. La gauche face au renouveau et à la régression tchécoslovaques (1968-1978). Paris 1985, s. 70-72. PCF posléze, ostatně jako naprostá většina komunistických stran v Evropě, prošla procesem, který mohl být považován za obdobu československé normalizace. Ve Francouzské komunistické straně vše vyvrcholilo na jejím XIX. sjezdu v únoru 1970 v Nanterre, kde těžce nemocného Waldeck-Rocheta na postu generálního tajemníka vystřídal prosovětský Georges Marchais. Delegáti sjezdu přistoupili k vylučování ze strany těch osobností, které se stavěly na obranu Pražského jara, jako byl filozof Roger Garaudy, a k pozastavení podobně smýšlejících komunistických periodik Démocratie nouvelle a Les Lettres françaises. Srov. Grémion, Pierre: Méprises, résistances, malentendus : la gauche française face au Printemps de Prague. In: Le Printemps de Prague 1968. Edd. F. Fejtö - J. Rupnik. Bruxelles 1999, s. 225, 228.

35 Zatímco PSU se sympatiemi studovala tamější model autonomního řízení odmítající jak posun směrem k sociální demokracii, tak dogmatické uplatňování pouček marxismu-leninismu, Mollet i Mitterrand se k československému reformnímu hnutí stavěli nanejvýš opatrně. Snad to bylo i tím, že oba v předcházejících letech navštívili ČSSR v naději, že se Novotného vedení stane jejich partnerem v nově navázaném dialogu mezi oběma zeměmi o problematice vztahů v Evropě. Srov.: Tamtéż, s. 74, 76-77; Upevñovat spolupráci pokrokových sil. Rudé právo, 12. 10. 1966, č. 282, s. 1; F. Mitterrand príiat soudruhem A. Novotným. Rudé právo, 14. 11. 1967, č. 314, s. 1.

36 Novinář a činovník PSU Gilles Martinet upozorňoval zejména na Mitterrandovy názory na tuto otázku, které odrážely i smýšlení mnoha Francouzů a blížily se i politice prosazované prezidentem republiky de Gaullem, totiž že zájmem Francie je využívat rovnováhy panující mezi Washingtonem a Moskvou. Poukázal rovněž na tradiční afinitu mezi Francií a Ruskem. Srov. Martinet, Gilles: Les ambiguïtés de la gauche française face au Printemps de Prague. In: Le Printemps de Prague 1968. Edd. F. Fejtö - J. Rupnik. Bruxelles 1999, s. 233. 
jeho pozice slábla úměrně tomu, jak francouzští komunisté stále viditelněji přistupovali na sovětská stanoviska v československé otázce. Nezměněn zůstal i program strany, a to i ve věci jednoty levice, která byla obecně vítána, ovšem až poté, co vznikne shoda na jejím společném vládním programu. $\mathrm{V}$ jedné rovině $\mathrm{k}$ jisté modifikaci přece jen došlo. Dosud komunisté za své hlavní soupeře prezentovali gaullisty, ačkoliv, jak jsme viděli, jejich voliči to opakovaně odmítli potvrdit. Květen roku 1968 a vše co následovalo, je naopak přivedlo $\mathrm{k}$ zostření svého boje s gauchismem, tedy s radikálně levicovými proudy. Již v červenci 1968 ústřední výbor toto tzv. levičáctví prohlásil za hlavní nebezpečí pro Francii. Radikální levice podle jeho názoru vyzývala k revolučnímu převratu, což nebyla vhodná cesta k socialismu tak, jak to potvrdil XVIII. sjezd PCF v roce 1967. ${ }^{37}$ Studentské hnutí se však nepřetransformovalo do politického uskupení a jediná strana, která mu byla ideologicky i personálně blízká, tedy PSU, sice jako jediná levicová formace v červencových volbách posílila, i tak její voličská podpora nepřekročila hranici pěti procent. Hnutí si tedy nedokázalo zajistit vliv na další vývoj na levici.

Daleko závažnějším rozhodnutím komunistů bylo opuštění sice neoficiálního, přesto dosud fungujícího volebního kartelu PCF se stranami tvořícími FGDS před předčasnými prezidentskými volbami, které byly vypsány příštího roku 1969 po odstoupení Charlese de Gaulla z funkce prezidenta republiky. PCF totiž do nich postavila vlastního kandidáta bez dohody s jakoukoli další politickou stranou. Můžeme v tomto kroku spatřovat výraz sebevědomí nabitého díky událostem z bouřlivého roku 1968? To jistě ne. Spíše k němu dospěla díky vývoji uvnitř Federace.

Křehká FGDS podstatu své existence odvozovala od perspektivy vytvoření jediné velké nekomunistické levicové strany, která by vystřídala dosud vládnoucí pravici. Jak jsme si výše dokázali, o správnosti zvoleného postupu formou federace, či spiše konfederace politických uskupení nepřipravených ke skutečné integraci, se pochybovalo napříč těmito stranami i jejich vnitřními frakcemi. Katastrofální volební výsledky z července 1968 tyto pochybnosti přetavilo v přímé odmítnutí. Krátce po volbách politické byro FGDS tvrdilo, že se podařilo omezit nástup pravice a že má Federace pokračovat v procesu vytváření oné velké demokratické socialistické strany. ${ }^{38}$ Tomu však nevěřili ani její členové, natož veřejnost, která přistoupila na gaullistickou politiku vyvolávání strachu z francouzské obdoby československého Vítězného února. ${ }^{39}$ Bylo třeba vyvodit důsledky. Když se po volbách sestavovaly orgány nově zvoleného Národního shromáždění, sešel se i obnovený poslanecký klub FGDS, který vyzval předsedu Federace Mitterranda k odstoupení z této funkce a do svého čela opět zvolil kritika Mitterrandových, ale i Molletových koncepcí

37 M. Waldeck Rochet estime que le "gauchisme » est aujourd'hui «le danger le plus pressant ». Le Monde, roč. 25, č. 7306, 11. 7. 1968, s. 7 .

38 "L'union de la gauche a permis de limiter la poussée réactionnaire " estime le bureau politique de la F.G.D.S. Le Monde, roč. 25, č. 7302, 6. 7. 1968, s. 9.

39 Na to poukázal např. deník Le Monde. Dle jeho názoru nádech puče mohlo mít už vystoupení Françoise Mitterranda z jara roku 1968, v němž ohlásil ochotu převzít vládní odpovědnost (Vítěznému únoru se ve Francii řŕká Pražský puč). Francouzi totiž mohli mít pocit, že nekomunistické strany jsou ve vleku komunistů, kteří požadovali klíčové resorty a zdůrazňovali svou převahu potvrzenou příznivějšími volebními zisky v červenci 1968. Les sommets de la crise. Le Monde, roč. 25, č. 7302, 11. 7. 1968, s. 6. 
Gastona Defferra. ${ }^{40}$ Mitterrand byl označen za hlavního viníka propadu FGDS nejen pro svoji činnost $\mathrm{v}$ průběhu květnové krize, ale i pro svou vizi spolupráce s PCF. Již jsme naznačili, že po 21. srpnu 1968 se i v řadách francouzské nekomunistické levice vzedmula vlna antikomunismu. Pozornost kritiků spolupráce FGDS s komunisty se tedy opět upřela na Mitterranda. Ten se tedy rozhodl dne 7. listopadu 1968 vzdát své funkce předsedy Federace a stáhl se z aktivní politiky. ${ }^{41}$ Nebylo to samozřejmě definitivní rozhodnutí, protože Mitterrand vždy uměl čekat na svou př́ležitost. Nyní však měli přijít na řadu jeho kritici. Je totiž něco jiného zbavit se svého předsedy a pokračovat dále, nebo svou politiku zásadně změnit.

Nejblíže opuštění dosavadních konceptů stála radikální strana. Její členstvo vždy přistupovalo k perspektivě jednotné levice rezervovaně a zejména se stavělo kriticky k dialogu s PCF. Nyní mezi ním sílily hlasy vyzývající k posunu do politického středu. Federaci však radikálové nakonec neopustili, opět se u nich projevila jistá neschopnost vést vlastní politiku a závislost na SFIO. ${ }^{42}$ Ani socialisté nakonec nepřikročili k žádnému zásadnímu přehodnocení své politiky. O ni se pokoušel zmíněný Gaston Defferre, jenž propagoval opuštění dosavadní ideologické základny strany. Ta se měla spíše než k socialistické orientaci hlásit k švédskému modelu sociální demokracie. Na sociálnědemokratických myšlenkách dle něj měla stavět i FGDS. Do jisté míry tak oprášil svůj starý koncept sjednocování levice bez komunistů, zato blíže politickému středu. Národní rada socialistů v listopadu 1968 však Defferrovy návrhy odmítla, socialisté se i nadále drželi linie, nad níž držel ochrannou ruku jejich dlouholetý generální tajemník Guy Mollet. ${ }^{43}$ Přestože Mollet na nadcházejícím sjezdu SFIO svolaném v prosinci 1968 do Puteaux ohlásil, že odejde ze své funkce, jeho vliv zjevně ve straně převažoval. Socialisté se sice rozhodli pro vznik nové socialistické strany, ta však měla být dle jejich představ vybudována na bázi SFIO při zachování stávající politické orientace strany. Odpůrci Molletovy linie neuspěli ani v otázce jednání s komunisty. Sjezd se vyslovil ve prospěch pokračování dialogu s PCF ${ }^{44}$ Programové rozdíly zůstávaly nezměněny, reakce francouzských komunistů na vývoj v ČSSR vzbuzovaly nedůvěru, socialisté se však rozhodli, že se ani oni nevydají cestou rozchodu s minulostí.

40 Les députés socialistes et le comité exécutif du parti radical s'interrogent sur les orientations de la Fédération. Le Monde, roč. 25, č. 7307, 12. 7. 1968, s. 7.

41 Lacouture, Jean: Mitterrand. Une histoire de Français. 1. Les risques de l'escalade. Paris 1998, s. 343-344.

42 Radikálové své setrvání v tomto uskupení omlouvali nutností čelit jednotně reformě Senátu, již prosazoval Charles de Gaulle proto, aby ji následně Francouzi potvrdili svým ano v připravovaném referendu, přičemž tento souhlas by byl především vyjádřením podpory svému prezidentovi. Fogacci, Frédéric: « Totalement passifs, totalement négatifs »?, s. 59.

43 M. Gaston Defferre : L'intérêt des radicaux est de venir avec nous. Le Monde, roč. 25, č. 7369, 22./23. 7. 1968, s. 7; La décision SFIO sur les projets de fusion : La nouvelle formation ne peut être que socialiste. L'Humanité, č. 7527,4 . 11. 1968, s. 1 .

44 Le Congrès SFIO a commencé ses travaux à Puteaux. L'Humanité, č. 7568, 21. 12. 1968, s. 4; Un pas en arrière. L'Humanité, č. 7569, 23. 12. 1968, s. 1. 


\section{Prezidentské volby v roce 1969}

Jediným hmatatelným vyvozením personálních a programových důsledků z krizí roku 1968 tak byl jen odchod Mitterranda z čela FGDS. K jedné zásadní změně přesto nakonec došlo. Když po odmítnutí reformy Senátu odstoupil prezident republiky Charles de Gaulle a byly vypsány předčasné prezidentské volby, dostala levice další příležitost postavit silného kandidáta, jako se jí to podařilo v minulé volbě v roce 1965. Přestože se za závažnější ze zmíněných kritických momentů považovalo bouřlivé francouzské jaro 1968, v tomto okamžiku se odhalil vliv toho druhého, tedy násilného ukončení československého reformního snažení intervencí v srpnu 1968. Francouzská komunistická strana ji sice odmítla, k dalšímu vývoji v ČSSR však již mlčela a zcela přijala sovětskou politiku a nezavrhla počínající tzv. normalizaci. V těchto podmínkách se nezdálo ani Molletovi, který dosud důsledně obhajoval dialog s PCF, vhodné, aby jeho strana, potažmo Federace, postavila společného levicového kandidáta. SFIO se proto rozhodla, že opráší kandidaturu Gastona Defferra, který nikdy nehledal podporu u komunistů. ${ }^{45}$

Za populárního starostu města Marseille Defferra se postavil stále velice respektovaný Pierre Mendès-France. Tento tah se však neukázal štastným. Mendès-France do roku 1968 spolupracoval s PSU, takže teoreticky mohl socialistům přivést nové voliče v duchu pozměněné ideje kooperace levice. Pro podporovatele obou však spolupráce Defferra s kritikem SFIO a páté republiky jako takové, jejichž program cílil především na ekonomická témata, nebyla dostatečně srozumitelná, nedokázala mobilizovat levicové voliče, a to ani radikálně smýšlející př́íznivce PSU, ani socialistické SFIO.

Řada z nich proto podpořila Alaina Pohera, který ohlásil kandidaturu. ${ }^{46}$ Alain Poher byl představitelem Demokratického středu, tedy politické strany, která sama o sobě nepatřila mezi ty nejsilnější, avšak jako dosavadní předseda Senátu, kterého se dotýkala referendem odmítnutá reforma, byl vnímán jako obhájce parlamentního režimu, který jako jediný může porazit gaullistického kandidáta. Přilákal tak mnohé protigaullistické smýšlející Francouze, kteří v předchozích volbách na doporučení SFIO a radikální strany volili Françoise Mitterranda. ${ }^{47}$ Za Defferra se nepostavili ani radikálové, kteří upřednostnili právě Alaina Pohera. To předznamenalo definitivní rozpad FGDS, který již delší čas visel ve vzduchu.

Z výše uvedeného zjevně vyplývá, že Defferre byl zcela nepřijatelný také pro komunisty. Komunističtí voliči by ho nejspíše odmítli ještě výrazněji než Mitterranda v roce 1965.

45 Např. Charles Fuzier shrnul mínění SFIO o postojích komunistů v socialistickém listu Le Populaire, když v chování PCF viděl „něco středověkého nebo inkvizitorského“. Srov.: Le parti communiste français en posture difficile. Le Monde, roč. 26, č. 7687, 1. 10. 1969, s. 4.

46 Bastien, François: Histoire des candidatures à l'élection présidentielle. Pouvoirs, 2011/3, č. 138, s. 8, https:// www.cairn.info/revue-pouvoirs-2011-3-page-5.htm, citováno 16. 5. 2016; Za Pohera se otevřeně postavily i mnohé místní organizace SFIO. Srov. Ranger, Jean: L'électorat communiste dans l'élection présidentielle de 1969. Revue française de science politique 20, 1970, č. 2, s. 287-288, http://www.persee.fr/doc/ rfsp_0035-2950_1970_num_20_2_393225, citováno 16. 5. 2018.

47 Lancelot, Alain - Weil, Pierre: L'évolution politique des électeurs français, de février à juin 1969. Revue française de science politique 20, 1970, č. 2, s. 261-265, https://www.persee.fr/doc/rfsp_0035-2950_1970_ num_20_2_393224, citováno 16. 5. 2018. 
PCF se proto rozhodla nabídnout Francii vlastního kandidáta, jímž se stal konzervativec Jacques Duclos. Samostatně postupovala i PSU, když do volby vyslala svého generálního tajemníka Michela Rocarda. A mezi levicové kandidáty se zařadil ještě Alain Krivine, představitel nedávno vzniknuvší Komunistické ligy, která se zrodila v prostředí revolučně založené mládeže.

Levicově orientovaní Francouzi si tedy mohli vybírat mezi čtyřmi levicovými osobnostmi. Radikální strana a část SFIO se pak postavily za středového Pohera. To snad ani nemohlo dopadnout jinak než zvolením gaullistického kandidáta. Stalo se tak až v druhém kole, kde se gaullista Georges Pompidou utkal s Alainem Poherem. Jacques Duclos na třetím místě a Michel Rocard na pátém místě vybojovali zisk přibližně odpovídající výsledkům svých stran v parlamentních volbách v roce 1968, tedy 21,3, resp. 3,6\% hlasů. Katastrofální propad zaznamenali socialisté, protože Gaston Defferre skončil až čtvrtý s pouhými pěti procenty. ${ }^{48}$

\section{Závěr}

Po překvapivém úspěchu Françoise Mitterranda v roce 1965, za něhož se postavili radikálové, SFIO, PSU i komunisté, a navýšení počtu mandátů pro své strany díky neoficiálnímu volebnímu kartelu PCF a FGDS v roce 1967 přišly neúspěšné parlamentní volby v červnu 1968 a nakonec i prezidentské volby z června 1969, kdy se levicoví nominanti nedostali ani do druhého kola volby. To byla především rána pro projekt spolupráce francouzské levice, který se rodil od roku 1965. Strana PSU po celé sledované období zůstala ve stále výraznější izolaci od ostatních levicových formací. Komunisté se programově k jednotě levice hlásili. Zdůrazňovali možnost specifické francouzské cesty k socialismu bez nutnosti provést revoluci a stáli za liberalizačními snahami jejího generálního tajemníka Waldeck-Rocheta. Trvali ovšem na vypracování společného vládního programu PGF a FGDS, jenž byl přitom při známých zásadních rozdílech v pohledu na vnitřní, ale zejména zahraniční politiku země dosti obtížně realizovatelný. Jelikož si udrželi slušné volební výsledky přes vlnu antikomunismu vyvolanou srpnovou okupací Československa a obavami z revolučního výbuchu ve Francii o několik měsíců dříve, neměli potřebu na svých postojích nic měnit.

Největším poraženým se stala Federace demokratické a socialistické levice tvořená radikály, SFIO a Konventem republikánských institucí. Založena byla s cílem stát se vưdčí silou francouzské levice. Její členové přitom museli mnohé zkousnout, což se týkalo radikálů, kteří často tendovali spíše k politickému středu. Vnitřně rozpolcená byla i SFIO. Tu sice ovládal její generální tajemník Guy Mollet jakožto ochránce jejího tradičně socialistického zaměření, nemálo jejích členů však podporovalo Gastona Defferra, zastánce moderněji pojaté levicové politiky a odpưrce vyjednávání s komunisty. CIR se potom zaměřoval na promýšlení budoucnosti levice v rámci politické struktury páté republiky,

48 Lancelot, Marie-Thérèse - Lancelot, Alain: Atlas des élections françaises de 1968 et 1969. Revue française de science politique 20, 1970, č. 2, s. 312-328, http://www.persee.fr/doc/rfsp_0035-2950_1970_ num_20_2_393226, citováno 16. 5. 2018. 
voliče si však jako takový nezískal. Jeho jedinou výraznou osobností byl Mitterrand. Ten mnoho sil investoval zejména do Federace jako celku. Když těžkopádná FGDS, obtížně hledající cestu ke své transformaci v jednotné uskupení, ne-li přímo politickou stranu, utrpěla volební porážku v roce 1968, kdy výrazně doplatila na květnové a červnové události ve Francii, začal její faktický rozpad. Z jejího čela odstoupil Mitterrand a strany, které ji tvořily, rezignovaly na společný postup v prezidentské volbě 1969. Rozpadl se tak nejen levicový volební kartel, ale i jedna ze struktur, které ho tvořily.

Znamenalo to, že myšlenka jednotného postupu levice byla odsouzena k zániku? Většinový volební systém a přímá prezidentská volba velely $\mathrm{k}$ tomu, aby tomu tak nebylo. Francouzský stranický systém se musel změnit. Proti pravici reprezentované silnou gaullistickou stranou se mohlo postavit jen silné levicové uskupení. Zatímco radikálové a PSU se na další integraci levice odmítli podílet, čímž se odsoudili k živoření na okraji politického spektra, ohniskem jednoty levicových sil se stali socialisté. Jejich SFIO se transformovala v Socialistickou stranu. To samo o sobě nemuselo stačit. Proč by jen tímto přilákali více voličů, než tomu bylo v končících 60. letech 20. stoletî́? Osudovým se stalo rozhodnutí Françoise Mitterranda vrátit se do politiky. Svưj cíl, jímž bylo sjednocení levice, již nechtěl realizovat prostřednictvím svého Konventu. Ten sice ještě v prosinci 1969 vyzýval k obnovení Federace bez radikálů, zato s PSU, ${ }^{49}$ Mitterrand se však nakonec rozhodl, že ke svým záměrům využije nově zformovanou Socialistickou stranu, v jejímž čele již nestál konzervativní Mollet. Získal si v ní mnoho zastánců, až se nakonec stal jejím generálním tajemníkem na sjezdu v Épinay v červnu $1971 .{ }^{50} \mathrm{~A}$ protože mu bylo zřejmé, že pouhé včlenění CIR do Socialistické strany k volebním úspěchům nepovede, prosadil obnovení dialogu s PCF. Ani jakási forma normalizace Francouzské komunistické strany, ani její postoje k Československu v tom neměly zabránit. Na počátku 70. let 20. století se obě strany dostaly ke konkrétnější diskuzi o společném vládním programu Mitterrandovy strany s PCF, jejímž novým generálním tajemníkem byl konzervativní Georges Marchais. Okupace ČSSR byla cíleně upozaděna, např. programové setkání socialistů konané v listopadu 1972, tedy tzv. Studijní dny (Journées d'études), měly dokázat, že Pražské jaro a vytvářený program společného vládnutí PS a PCF, nebyly v rozporu. ${ }^{51} \mathrm{Nad}$ ideologickými rozpory bránícími významnějšímu sblížení levicových formací v 60. letech zvítězil pragmatismus vycházející z logiky francouzského volebního systému. Tu Mitterrand pochopil již v roce 1965, ale až po krizi levice v letech 1968 a 1969 našel efektivní cestu vedoucí nakonec až k převzetí moci v roce 1981, kdy se Mitterrand stal prezidentem republiky a levicová koalice zahrnující komunisty obdržela většinu poslaneckých mandátů.

49 La Convention, le parti socialiste et le PSU devraient constituer une fédération. Le Monde, roč. 26, č. 7745, 7./8. 12. 1969, s. 8.

50 Julliard, J.: Mitterrand, s. 350-355.

51 Grémion, P.: Méprises, résistances, malentendus : la gauche française face au Printemps de Prague, s. 228-229. 


\section{Die Einigung aufgeschoben. Der Zerfall des Wahlkartells linker Kräfte und die Präsidentenwahl in Frankreich nach der politischen Ereignissen in 1968}

Diese Studie behandelt den Annäherungsprozess von französischen politischen Parteien in der zweiten Hälfte der 60er Jahre des 20. Jahrhunderts. Das Wahlergebnis ihres gemeinsamen Kandidaten François Mitterrands in der Präsidentenwahl in 1965 zeigte, dass nur ein koordiniertes Vorgehen der Linksopposition Aussicht auf Erfolg hat. Traditionelle demokratische Parteien bildeten daher mit der Kommunistischen Partei Frankreichs ein Kartell, das zum einzigen Ziel die Einigung der französischen Linken hatte. Sie stießen jedoch auf ideologische Hürden und Unterschiedlichkeit der Programme, z. B. im Bereich internationaler Beziehungen. Die Brüchigkeit dieses Konstrukts zeigte das Jahr 1968. Die durch massive Studentenbewegung ausgelöste politische Krise in Frankreich schwächte wesentlich die linken Parteien. Der Einmarsch der Truppen der Warschauer-Pakt-Staaten in die Tschechoslowakei diskreditierte folglich die französischen Kommunisten, da sie nicht im Stande waren, sich völlig vom Vorgehen der Sowjetunion zu distanzieren und somit zu zeigen, dass die Entstaliniesierung ihrer Partei ernst gemeint war. Das Wahlkartell zerfiel und in Präsidentenwahl 1969 stellten sich dem Rechts-Kandidaten gleich vier Vertreter der Linken. Die Studie erklärt, dass die Parteien an ihren traditionellen Programmschwerpunkten festhielten. Ihre Vorstellungen über weiterer Annäherung waren nicht genügend konkret und sie waren so nicht fähig, sich im Moment der politischen Krise auf ein gemeinsames Vorgehen zu einigen. Es zeigte sich, dass sie andere Wege finden müssen. 